\title{
Endovascular Balloon Treatment of a Failing Arteriovenous Fistula. A Case Report
}

\author{
Emmanuel Auchi Edafe $^{1 *}$, Narendra Nath Khanna², Peter Dodo Yakubu² \\ ${ }^{1}$ Department of internal Medicine, University of Port Harcourt Teaching Hospital, Port Harcourt \\ ${ }^{2}$ Clinical Associate (Fellow- Interventional Cardiology \& Vascular Interventions) Indraprastha Apollo Hospital, New Delhi \\ *Corresponding Author: Emmanuel Auchi Edafe, Department of internal medicine, University of Port Harcourt Teaching Hospital, Port \\ Harcourt \\ Received: December 30, 2020; Accepted: February 12, 2021; Published: February 19, 2021 \\ Citation: Emmanuel A. Edafe., Narendra N. Khanna., Peter D. Yakubu., (2021) Endovascular Balloon Treatment of a Failing Arteriovenous \\ Fistula. A Case Report. J. Clinical Cardiology and Cardiovascular Interventions, 4(4); Doi:10.31579/2641-0419/124
}

Copyright: ( 2021 Emmanuel Auchi Edafe, This is an open-access article distributed under the terms of the Creative Commons Attribution License, which permits unrestricted use, distribution, and reproduction in any medium, provided the original author and source are credited.

\begin{abstract}
BACKGROUND: Arterio-venous (AV) fistula is created for patients requiring renal replacement therapy (hemodialysis and hemofiltration). A failing Ass-V fistula requires urgent treatment to keep it patent. Understanding the simple tips and tricks will contribute to the quality of life for the patient with end-stage renal disease and reducing radiation dose to the operator.

CASE SUMMARY: A 77 year old male with end-stage renal disease, hypertension and coronary artery disease. He has been on regular haemodialysis after A-V fistula (left forearm) was constructed in 2013. He presented with 2 weeks history of A-V fistula occlusion. Examination was essentially normal. Serum sodium=136mmol/1, potassium $=5.5 \mathrm{mmol} / \mathrm{l}$ urea $=100 \mathrm{mg} / \mathrm{l}$, creatinine $=3.5 \mathrm{mg} / \mathrm{dl}$. The Doppler scan showed $50 \%$ stenosis just proximal to the anastomosis with calcification. Percutenous arteriography and venography was done with non-compliance balloon $(3 \times 12 \mathrm{~mm})$ up to $24 \mathrm{~atm}$. The post procedure venography showed restoration of flow across the fistula.
\end{abstract}

CONCLUSION: Endovascular treatment of a failing A-V fistula can be life saving. The simple tips and tricks of using the groin route, reducing the concentration of contrast and maneuver devices may contribute to safety and reduce radiation to the operator.

Key words: endovascular treatment; failing arteriovenous fistula.

\section{Introduction}

Arteriovenous fistulas are the preferred route for hemodialysis access in patients with end-stage renal disease. These surgically constructed fistulas, usually between the radial artery and the cephalic vein. They have proven to be the best permanent vascular access for hemodialysis based on durability and low risk of complications when compared to other forms of vascular access [1]. AV fistula is a connection made between a highpressure arterial system and a low- pressure venous system. Vessel wall stress occurs and causes nitrous oxide release and vein dilation.

The fistula flow depends on high arterial volume flow, which should be greater than $200 \mathrm{~mL} / \mathrm{min}$ to maintain adequate patency and use during dialysis [2]. A stenosis in any part of the circuit (arterial inflow or venous outflow) can limit forward flow. When these mechanisms are favorable, the vein dilates and produces a usable fistula. Percutaneous transluminal angioplasty (PTA) is one of established. The emphasis of this case report in the simple tips and tricks that may reduce radiation to the operator and contrast induced nephropathy to the patient

\section{CASE PRESENTATION}

A 77 year old male, hypertensive with CKD on RRT via AVF for the past 4 years. He presented with 14 days history of fistula block that necessitated temporary use of the femoral assess. Examination findings revealed absence of thrill in the region of the A-V Fistula at left forearm. $\mathrm{RBG}=84 \mathrm{mmol} / \mathrm{l}$, serum urea $=161 \mathrm{mmol} / \mathrm{l}$, serum creatinine $=8.1 \mathrm{mg} / \mathrm{dl}$ $\mathrm{Na}=136 \mathrm{mmol} / 1, \mathrm{~K}=5.5 \mathrm{mmol} / 1$, serum chloride $=103 \mathrm{mmol} / 1$.

Doppler ultrasound of the left upper limb (arterial and venous), showed $50 \%$ stenosis measuring $6 \mathrm{~mm}$ just proximal to the anastomosis site of the A-VF. Division of the draining cephalic vein is seen in the proximal forearm with flow diversion. He was then admitted for peripheral angiography and venography. Written informed consent was taken after explaining the procedure and the possible benefits and risks involved.

\section{PROCEDURE}

A 6-French vascular introducer sheath was inserted percutaneously into the femoral artery, and was advanced towards the left subclavian, through the axillary, brachial and the radial arteries and into the radiocephalic fistula into the cephalic vein. 
A set of diagnostic arteriograms, venograms and fistulograms were produced. The length and diameter of the Stenotic segment was measured using the radiograph of the fistulograms. This showed $90 \%$ stenosis of the outflow tract of the fistula. The stenosis was traversed with a 0.035 -inch guide-wire (Terumo,Tokyo, Japan) via the introducer sheath.

Two thousand five hundred units of heparin were administered through the side port of the introducer sheath into the AVF. The selected balloon catheter was then inserted across the stenosis using the guide-wire; this was assisted by fluoroscopy.
The non-compliance balloon $(3 \times 12 \mathrm{~mm})$ was inflated with a pressure inflation device up to $24 \mathrm{~atm}$. Inflation was sustained for 60 seconds and the process was repeated two or three times.

Heparin infusion was started immediately for 24 hours followed by oral aspirin $150 \mathrm{mg} /$ day as maintenance prophylaxis against thrombosis. Arteriovenous fistulograms done immediately after procedure showed adequate flow.

\section{PICTURES}

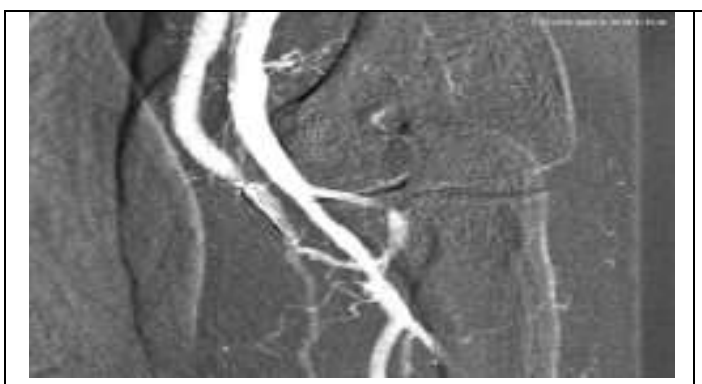

A: Road map

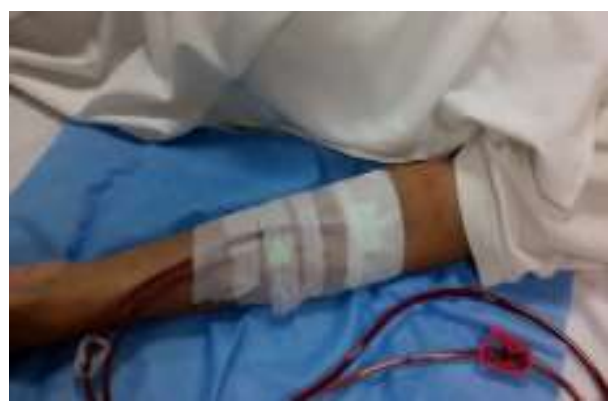

During follow up for hemodialysis post-procedure.

Evaluation of arteriography and venography revealed good flow with adequate thrill. One week post balloon dilatation, patient started using the A-V fistula for hemodialysis

\section{DISCUSSION}

Patient with AVF could experience primary or late failure as complication. Primary failure is the defined as the failure of AVF to mature or failing within the first three months of its use. [3]. Late (secondary failure) is the failure that occurs after three months of its use in hemodialysis [3]. Our patient has the late form of failing arteriovenous venous fistula. The procedure could be done via the groin or the radial route. In this patient, we use the groin route because the operator is at a distant from the source of radiation compared to the radial route.

While panning the procedure, we task into consideration that the patient is living with end stage renal disease and that he is at high risk of contrast induced nephropathy (CIN). This was factor in, making us to use isomolar (visipaque) diluted with normal saline in ratio of 1:1. During the procedure, we started with guide catheter with a guide wire, but we could not advanced the catheter due to kincking. This lead us to change from the guiding catheter for long sheath. This improved our ability to assess the lesion with ease.

\section{CONCLUSION}

Endovascular treatment of a failing A-V fistula can be life saving. It is easy, safe and with rare complication. Observing these simple but important tips and tricks make the operator and patient safe.

\section{TRICKS AND TIPS}

1. The prefer route should be from the groin to minimize radiation

2. Minimize contrast use by diluting with normal saline in a ratio of $1: 1$

3. Use long sheath when you encounter difficulty with guide catheter

\section{References}

1. Malovrh M. Non-invasive evaluation of vessels by duplex sonography prior to construction of arteriovenous fistulas for hemodialysis. Nephrol Dial Transplant. 1998;13(1):125-129.

2. Schanzer H, Skladany M. Vascular access for dialysis. In: Haimovici H (ed). Haimovici's Vascular Surgery. 4th ed. Cambridge, United Kingdom: Blackwell Science. 1996:10281041.

3. Lee T, Morkrzyck M, Moist L, Maya I, Vazquez M, Lok C. Standardized definitions of hemodialysis vascular access. Semiin Dial. 2011;24(5):515-524. 


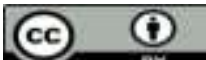

This work is licensed under Creative Commons Attribution 4.0 License

\section{To Submit Your Article Click Here: Submit Manuscript}

DOI:10.31579/2641-0419/124
Ready to submit your research? Choose Auctores and benefit from:

* fast, convenient online submission

* rigorous peer review by experienced research in your field

* rapid publication on acceptance

* authors retain copyrights

* unique DOI for all articles

* immediate, unrestricted online access

At Auctores, research is always in progress.

Learn more www.auctoresonline.org/journals/clinical-cardiology-andcardiovascular-interventions 